\title{
Yield and Yield Attributes of Maize as Influenced by Organic Manures and Inorganic Fertilizers under Maize-Chickpea Cropping Sequence
}

\author{
Y. C. Lakum, H. K. Patel*, G. G. Patel, C. F. Makwana and P. D. Patel \\ Department of Agronomy, B.A. College of Agriculture, Anand Agricultural University, \\ Anand-388110, Gujarat, India \\ *Corresponding author
}

\begin{tabular}{|l|}
\hline Ke y w o r d s \\
Maize, FYM, castor \\
cake, \\
vermicompost, \\
AGR, CGR, seed \\
and straw yield \\
\hline Article Info \\
\hline $\begin{array}{l}\text { Accepted: } \\
\text { 11 June } 2020 \\
\text { Available Online: } \\
\text { 10 July } 2020\end{array}$ \\
\hline
\end{tabular}

\section{A B S T R A C T}

A field experiment was carried out at the College Agronomy Farm, B. A. College of Agriculture, Anand Agricultural University, Anand during two consecutive Kharif and rabi seasons of the year 2015-16 and 2016-17 with a view to study the Yield and yield attributes of maize as influenced by organic manures and inorganic fertilizers on maize (Zea mays L.)-chickpea (Cicer arietinum L.) cropping sequence. The experiment comprised of four levels of organic manures viz., Control $\left(\mathrm{M}_{1}\right), \operatorname{FYM}\left(\mathrm{M}_{2}\right)$, castor cake $\left(\mathrm{M}_{3}\right)$, vermicompost $\left(\mathrm{M}_{4}\right)$; and two levels of Recommended dose of fertilizers (100\% $\left(F_{1}\right)$ and $75 \%\left(F_{2}\right)$ of $\left.R D F\right)$ and two levels of sulphur $\left(0\left(S_{1}\right)\right.$ and $\left.20\left(S_{2}\right) \mathrm{kg} \mathrm{S} / \mathrm{ha}\right)$. The experimental plots were laid out in Randomized Block design (factorial) with four replications. The kharif maize was fertilized as per different treatment combinations and its residual effect was study on rabi chickpea. Results revealed that application organic manure $\left(\mathrm{M}_{2}: 10 \mathrm{t} \mathrm{FYM/ha)}\right.$ recorded non-significant response on plant population at 20 DAS and at harvest and number of cobs/plant. Application of $10 \mathrm{t} \mathrm{FYM/ha}\left(\mathrm{M}_{2}\right)$ and 100 $\% \operatorname{RDF}\left(\mathrm{F}_{2}\right)$ was recorded significantly highest plant height, number of leaves, dry matter accumulation/plant, AGR, CGR, length of cobs, girth of cob, seed index, seed and straw yield. The sulphur @ $20 \mathrm{~kg} \mathrm{~S} / \mathrm{ha}$ recorded significant response on plant height at 60 DAS, average weight of cob and seed yield of maize.

\section{Introduction}

Maize (Zea mays L.) is one of the most important cereal crops in the world agriculture economy both as a food for human being and a feed for animals. There is no cereal on the earth, which has such immense potential like maize and therefore, it occupies the pride place as, "Queen of cereals". In the world, maize ranks third amongst the food crops, next to rice and wheat. Maize is grown in almost all the states of India and it contributes nearly 9 per cent in the national food basket.

Maize is important not only because of its great adaptability to divergent conditions but also due to its high responsiveness to management practices particularly nutrient management. 
There is an increasing interest in the use of organic manures as a source of nutrient supply to crop production for sustainable soil productivity, ecological stability and to minimize the requirement for chemical fertilizers. Indian soils are poor in organic carbon due to its tropical climate. With the increasing soil degradation and cost of chemical fertilizers, there is a need to integrate them with organic sources, which are good for soil health besides supplying nutrients for longer period. Combined application of available organic source along with optimal dose of inorganic fertilizers assure high and sustained productivity in a cereal-legume cropping system due to regulated nutrient supply and reduced the losses of nutrients, beside lowering cost of production. Such information is lacking for the system as a whole on the light texture of semi-arid part of central India. Sulphur is a key element for higher crop production because it is require for the formation of protein, vitamins, and enzymes. Also constituent of amino acids and involve in various metabolic activities including photosynthesis, respiration and legume rhizobium symbiotic nitrogen fixation. Hence, the experiment was planned on maizechickpea cropping sequence to study the effect of organic manures and inorganic fertilizers on yield and yield attributes of maize with certain objectives.

\section{Materials and Methods}

The field experiment entitled, Direct and residual effect of organic manures and inorganic fertilizers on maize (Zea mays L.) chickpea (Cicer arietinum L.) cropping sequence was carried out during kharif and rabi seasons of the years 2015-16 and 201617 at College Farm, Department of Agronomy, B. A. College of Agriculture, Anand Agricultural University, Anand. The texture of the soil is loamy sand. The soil is very deep and fairly moisture retentive. The soil of experimental site had low organic carbon $(0.45 \%)$, low available $\mathrm{N}(250.88$ $\mathrm{kg} / \mathrm{ha})$, medium available $\mathrm{P}_{2} \mathrm{O}_{5}(48.54 \mathrm{~kg} / \mathrm{ha})$ and $\mathrm{SO}_{4}-\mathrm{S}(15.24 \mathrm{mg} / \mathrm{kg})$; and high available $\mathrm{K}_{2} \mathrm{O}$ (315.84 kg/ha). There were total four levels of organic manure like $\left(\mathrm{M}_{1}\right.$ : no manure, $\mathrm{M}_{2}$ : FYM $10 \mathrm{t} / \mathrm{ha}, \mathrm{M}_{3}$ : castor cake $1.0 \mathrm{t} / \mathrm{ha}$ and $\mathrm{M}_{4}$ : vermicompost $2.5 \mathrm{t} / \mathrm{ha}$ ); two levels of inorganic fertilizer $\left(\mathrm{F}_{1}: 75 \% \mathrm{RDF}\right.$ and $\mathrm{F}_{2}: 100$ $\% \mathrm{RDF})$ and two sulphur levels $\left(\mathrm{S}_{1}: 0 \mathrm{~kg} \mathrm{~S} / \mathrm{ha}\right.$ and $\mathrm{S}_{2}: 20 \mathrm{~kg} \mathrm{~S} / \mathrm{ha}$ ). The experimental design was Randomized Block Design (Factorial) with four replications. Recommended dose of fertilizer (120-60-0 kg/ha) was applied by urea and DAP chemical fertilizer and sulphur was applied in form of Gypsum to maize crop and residual effect was study on chickpea crop var. GG 2 (Gujarat Gram 2). All agronomical practices and plant protection measure was followed for better and successful crop production. The chickpea seeds were treated bio-fertilizer (Rhizobium thiogangnaticum) before sowing. The observation on growth and yield attributes were recorded by randomly selected five plants from net plot area and tagged all plants for further observations. The data of various parameters were statistically analyzed using analysis of variance (ANOVA) technique and the treatments were compared at 5\% levels of significance (Cochran and Cox, 1967).

\section{Results and Discussion}

\section{Effect of organic manure}

Data presented in Table1 revealed that application of FYM @ 10 t/ha was recorded significantly highest plant height $(63.60$, 152.90 and $189.40 \mathrm{~cm}$ at 30, 60 DAS and at harvest, respectively) and number of leaves/plant (8.55 and 13.19 at 30 and 60 DAS, respectively). The increased in plant height by FYM application might be due to improve in soil physico-chemical and 
biological properties there by better availability of plant nutrients and moisture which enhance plant growth. The significantly highest plant height and number of leaves/plant due to more activities of meristematic tissues of the plant producing more number of trifoliate, which ultimately increased total photosynthetic surface area of the plant. This contributed towards higher production of leaf. The results similar to those of the finding of Rajkumara et al., (2009) and Mundra et al., (2011).

Dry matter accumulation/plant at $30(32.15 \mathrm{~g})$ and 60 DAS (97.42 g), leaf area/plant at 30 DAS $\left(2000.7 \mathrm{~cm}^{2}\right)$ and at harvest $(3963.30$ $\mathrm{cm}^{2}$ ) ad leaf area index at 30 DAS (1.67) and at 60 DAS (3.30) was recorded significantly highest due to application of vermicompost @ $2.5 \mathrm{t} / \mathrm{ha}\left(\mathrm{M}_{4}\right)$. Total dry matter accumulation and leaf area/plant would be more meaningful criterion for assessing complete vegetative growth. Higher dry matter accumulation and leaf area might be due to the fact that organic manure provided favourable conditions which helped in availability of water, air and nutrients which might have attributed to better canopy growth. All these together contributed to increase production of dry matter/plant. These findings are in agreement with the results of Meena et al., (2011). Increasing leaf area index by application of organic manure might be due to addition of organic matter and other nutrients through organic manure. This might be attributed to increased root growth owing to better soil physical condition and consequently exploitation of greater soil volume by roots for nutrient absorption. The results are in harmony with those of Meena $e t$. al (2011) and Rajkumara et al., (2012).

Application of FYM @ $10 \mathrm{t} / \mathrm{ha}\left(\mathrm{M}_{2}\right)$ recorded significantly the highest value of absolute growth rate $(2.19 \mathrm{~g} / \mathrm{plant} /$ day $)$ and crop growth rate $\left(18.21 \mathrm{~g} / \mathrm{m}^{2} /\right.$ day $)$ at $30-60$ days of the crop. The increased in LAI and dry matter accumulation/plant might be attributed to better absorption of nutrients, imparted by sufficient air and moisture in the rhizosphere which helped in increasing expansion of leaf lamina and thereby increased dry matter accumulation. These results are in line of the results reported by Manjhi et al., (2016). The data presented in Table2 indicated that application of 10t FYM/ha reported highest number of length of cob $(16.68 \mathrm{~cm})$ and girth of cob $(14.47 \mathrm{~cm})$ but response on no. of cobs/plant was found non-significant. The increased in length and girth of cob under organic manure application might be due to adequate supply of plant nutrients directly to the plants and created favourable soil environment to increase nutrients uptake especially nitrogen, phosphorus and potash by seed, ultimately increased the water holding capacity of soil for longer time, which resulted in overall increase in growth of the plant resulting in more number of cobs/plant (Srinivasanarao et al., 2010).

Average weight of cob/plant (129.7 g) and seed index (24.4 g) were recorded significantly highest under FYM $\left(\mathrm{M}_{2}\right)$ application over castor cake $\left(\mathrm{M}_{3}\right)$ and vermicompost $\left(\mathrm{M}_{4}\right)$ application, The increased in average weight of cob/plant under organic manure application was might be due to ascribed to the fact that after proper decomposition and mineralization of applied organic manures. The slow release of nutrients during the entire crop growth period might also result into better plant growth. The increased in seed index under organic manure application was due to supply of nutrients to crop during growth period and thereby the better growth of crop, which helped the supply of sufficient photosynthates at the seed filling stage. This led to higher seed index under organic manure application. Perusal of data presented in Table 3 revealed application of FYM@10/ha recorded significantly highest seed yield (4249 kg/ha) and straw yield (6420 
$\mathrm{kg} / \mathrm{ha}$ ). An application of organic manure might have increased the availability of both the native and applied nutrients in the soil and substantially enhance their uptake by the plant, leading to overall improvement in the growth and yield attributing characters like number of cobs/ plant, length and girth of cob, average weight of cob and seed index. Secondly, maximum yield under the treatment of FYM might be due to the beneficial effects of FYM by way of regulated liberalization and balanced supply of nutrients, tilting microbial dynamics in favour of the crop growth and creation of salutary soil environmental condition for the crop growth. Similar results were also reported by Rajkumara et al., (2012), Ashoka et al., (2013) and Mukherjee (2014) during investigation.

\section{Effects of inorganic fertilizer}

Application of inorganic fertilizers effects was found non-significant in case of plant population at 20 DAS and at harvest (Table1) and number of cobs/plant (Table2) during course of investigation. Data presented in Table1 indicated that increased in plant height at $30(61.80 \mathrm{~cm}), 60$ DAS $(151.50 \mathrm{~cm})$ and at harvest $(187.40 \mathrm{~cm})$ and number of leaves/plant at 30 (8.11) and 60 DAS (12.72) was increased with the increase levels of fertilization i.e $\quad F_{2} \quad(100 \quad \% \quad$ RDF $)$. The increased in plant height and number of leaves/plant might be attributed to increased uptake of nutrients, which is a structural component of protein molecules and protoplasm which might have increased synthesis of protein and carbohydrates in favour of increasing cell division and elongation. Another result might be due to ascribed to favourable effect of nitrogen on expansion and division of cells with thinner cell walls, promoted vegetative growth and encouraged the formation of foliage by producing more carbohydrates, utilized in building up of new cells. These results were akin to those reported by Mukherjee (2014). Significantly the highest dry matter accumulation/ plant (31.03 g) and at 60 DAS $(94.58 \mathrm{~g})$, leaf area/plant at 30 DAS (1804.50 $\left.\mathrm{cm}^{2}\right)$ and at harvest $\left(3503.30 \mathrm{~cm}^{2}\right)$, leaf area index at 30 DAS (1.50) and at 60 DAS (2.92), AGR (2.12 g/plant/day) and CGR (17.65 $\mathrm{g} / \mathrm{m}^{2} /$ day) at $30-60$ DAS recorded due to application of $100 \%$ RDF $\left(\mathrm{F}_{2}\right)$. Dry matter production is the net resultant effect of different plant metabolic processes. Nutrient supplied to increase meristemic growth, number and size of the vegetative plant parts and number of leaves, induce greenness in plant leaves by increasing synthesis of chlorophyll, absolute growth rate, crop growth rate etc. All these parameters have helped in higher dry matter accumulation in plant parts. The increased in dry matter accumulation due to nutrient application was related to the favourable effect of nitrogen and phosphorus on plant growth as evident from plant height (Tetarwal et al., (2011). The reason for the higher leaf area at both period was the higher growth of morphological character. Also the effect of $\mathrm{N}$ on protein synthesis and meristematic growth through hormonal fusion was resulted in higher leaf area/plant. In case of the increased in LAI could be attributed to increase in vegetative growth such as plant height, number of leaves/ plant and dry matter accumulation/plant. Further, the relationship between leaf area and nitrogen changed with time and over most of the growth periods. Higher AGR and CGR recognized that nitrogen and phosphorus are the most important major plant nutrients, which plays vital role in plant growth and development. It was also due to the accelerated number of leaves/plant under $100 \% \mathrm{RDF}$, to which most of the photosynthates were diverted to the increasing sink. These results was also confirmed by Kumar and Singh (2001) and Kumar et al., (2002) 
An application of $100 \% \mathrm{RDF}\left(\mathrm{F}_{2}\right)$ recorded significantly the highest length of cob (15.89 $\mathrm{cm})$, girth of cob $(13.81 \mathrm{~cm})$, average weight of cob (125.70 g) and seed index (24.10 g). The higher yield attributes under $\mathrm{F}_{2}$ might be due to better nourishment of the crop as evident from higher removal of N, P and K by crop and fact that nitrogen might have hastened vigorous vegetative growth of the maize which might have stimulated the rate of photosynthesis and resulted into higher diversification of photosynthesis from vegetative to reproductive sink by Dechassa et al., (2013) and Mukherjee (2014).

Application of $100 \%$ RDF treatment $\left(\mathrm{F}_{2}\right)$ was recorded significantly the highest seed yield (4033 kg/ha) and straw yield (6134 kg/ha). The seed yield and straw yield was increased by $9.6 \%$ and $7.5 \%$ higher over $\mathrm{F}_{2}$ treatment. Application of $100 \%$ RDF recorded significantly the highest seed yield might be due to different levels of RDF was related to the differences in size of photosynthetic surface and to the relative efficiency of total sink activity, possibly a function of number of cobs/ plant, length and girth of cob, average weight/coband seed index, chlorophyll contents, which in turn influenced the direction of movement of substrates. Watson (1952) stated that nitrogen had far more potent influence on the total photosynthesis of plants through its effect on the leaf area.

Further, almost all growth, yield attributes and chemical characters were closely associated in the production of seed. All these might have cumulatively produced higher seed yield under the $100 \%$ RDF.

\section{Effect of sulphur}

Data presented in Table1 indicated that application of sulphur did not gave significant response on plant population, plant height at 30 and 60 DAS, number of leaves/plant, dry matter accumulation, leaf area/plant, leaf area index, AGR, CGR, number of cobs/plant, length of cob, girth of cob, seed index and straw yield. At harvest, significantly the tallest plant $(184.60 \mathrm{~cm})$ was observed by application of @ $20 \mathrm{~kg} / \mathrm{ha}\left(\mathrm{S}_{2}\right)$. Increased in plant height by application of sulphur might be due to effect of sulphur which has a function to metabolise growing parts of plants. It is directly related with cell division enlargement and elongation. Significantly the highest average weight of cobs (124.20 g) and seed yield $(3973 \mathrm{~kg} / \mathrm{ha})$ was observed under treatment $\mathrm{S}_{2}(20 \mathrm{~kg} \mathrm{~S} / \mathrm{ha})$. Increased higher average weight of cobs by application of sulphur might be due to stimulatory effect of $\mathrm{S}$ on tillering through cytokines synthesis and rapid conversion of synthesized carbohydrates into protein, consequent to increase in the number and size of growing cells, resulting ultimately into more average weight/cob (Srinivasanarao et al., (2010). Significantly, the highest seed yield was recorded with the treatment $S_{2}$. Further, treatment $S_{2}$ recorded 6.3 per cent higher seed yield over treatment $\mathrm{S}_{1}$. These might be due to the fact that sulphur application improved over all nutritional environment of the rhizosphere as well as plant system which could be more advantageous for profuse vegetative and root growth which activated higher absorption of phosphorus, sulphur and nitrogen from the soil and improved metabolic activities inside the plant. Sulphur plays a vital role in the synthesis of chlorophyll, a part of active centre of some enzymes. It also affects various metabolic processes, which ultimately helps in growth and development of plants.

\section{Interaction effects}

The treatment combination $\mathrm{M}_{2} \mathrm{~F}_{2}$ (Table4) gave significantly highest plant height at 60 DAS $(162.6 \mathrm{~cm})$, length of cob $(17.82 \mathrm{~cm})$, average weight of cob (131.0 g),seed yield (4547 kg/ha) and straw yield (6564 kg/ha). 
Table.1 Effect of direct and residual effect of organic and inorganic nutrient sources on maize yield attributes (pooled of Two years)

\begin{tabular}{|c|c|c|c|c|c|c|c|c|c|}
\hline \multirow[t]{2}{*}{ Treatment } & \multicolumn{2}{|c|}{$\begin{array}{l}\text { Plant population } \\
\text { (net/plot) }\end{array}$} & \multicolumn{3}{|c|}{ Plant height (cm) } & \multicolumn{2}{|c|}{ No. of leaves/plant } & \multicolumn{2}{|c|}{$\begin{array}{c}\text { Dry matter } \\
\text { accumulation/plant (g) }\end{array}$} \\
\hline & $\begin{array}{l}\text { At } 20 \\
\text { DAS }\end{array}$ & At harvest & $\begin{array}{l}\text { At } 30 \\
\text { DAS }\end{array}$ & $\begin{array}{l}\text { At } 60 \\
\text { DAS }\end{array}$ & At harvest & At $30 \mathrm{DAS}$ & At $60 \mathrm{DAS}$ & $\begin{array}{l}\text { At } 30 \\
\text { DAS }\end{array}$ & At 60 DAS \\
\hline \multicolumn{10}{|c|}{ Organic manure (M) } \\
\hline $\mathbf{M}_{1}$ & 74.8 & 70.9 & 51.5 & 135.6 & 170.9 & 6.78 & 10.67 & 27.68 & 83.24 \\
\hline $\mathbf{M}_{2}$ & 75.4 & 72.0 & 63.6 & 152.9 & 189.4 & 8.55 & 13.19 & 31.76 & 97.33 \\
\hline $\mathbf{M}_{3}$ & 74.7 & 71.6 & 60.4 & 147.5 & 177.5 & 7.66 & 11.82 & 30.09 & 92.40 \\
\hline $\mathbf{M}_{4}$ & 76.0 & 72.3 & 63.0 & 150.5 & 186.1 & 8.34 & 12.88 & 32.15 & 97.42 \\
\hline S.Em. \pm & 0.54 & 0.53 & 1.08 & 2.16 & 2.54 & 0.14 & 0.22 & 0.43 & 1.18 \\
\hline C. D. at $5 \%$ & NS & NS & 3.0 & 6.1 & 7.1 & 0.40 & 0.62 & 1.20 & 3.32 \\
\hline \multicolumn{10}{|c|}{ Inorganic fertilizer $(F)$} \\
\hline $\mathbf{F}_{1}$ & 75.3 & 71.7 & 57.4 & 141.7 & 174.5 & 7.55 & 11.56 & 29.80 & 90.61 \\
\hline $\mathbf{F}_{2}$ & 75.2 & 71.7 & 61.8 & 151.5 & 187.4 & 8.11 & 12.72 & 31.03 & 94.58 \\
\hline S.Em. \pm & 0.38 & 0.37 & 0.76 & 1.53 & 1.80 & 0.10 & 0.16 & 0.30 & 0.83 \\
\hline C. D. at $5 \%$ & NS & NS & 2.1 & 4.3 & 5.0 & 0.28 & 0.44 & 0.85 & 2.34 \\
\hline \multicolumn{10}{|l|}{ Sulphur (S) } \\
\hline $\mathbf{S}_{1}$ & 75.1 & 71.6 & 58.9 & 144.6 & 177.3 & 7.77 & 12.05 & 30.29 & 91.62 \\
\hline $\mathbf{S}_{2}$ & 75.3 & 71.8 & 60.3 & 148.6 & 184.6 & 7.89 & 12.23 & 30.55 & 93.57 \\
\hline S.Em. \pm & 0.38 & 0.37 & 0.76 & 1.53 & 1.80 & 0.10 & 0.16 & 0.30 & 0.83 \\
\hline C. D. at $5 \%$ & NS & NS & NS & NS & 5.0 & NS & NS & NS & NS \\
\hline Interaction & - & - & - & $\mathrm{MxF}$ & - & - & - & - & - \\
\hline C. V. \% & 4.1 & 4.1 & 10.2 & 8.3 & 7.9 & 10.31 & 10.22 & 7.92 & 7.21 \\
\hline
\end{tabular}


Table.2 Effect of direct and residual effect of organic and inorganic nutrient sources on maize growth attributes and Growth (pooled of Two years)

\begin{tabular}{|c|c|c|c|c|c|c|c|c|c|}
\hline \multirow[t]{2}{*}{ Treatment } & \multicolumn{2}{|c|}{$\begin{array}{l}\text { Leaf area/ plant } \\
\qquad\left(\mathrm{cm}^{2}\right)\end{array}$} & \multicolumn{2}{|c|}{$\begin{array}{l}\text { Leaf area index } \\
\text { (LAI) }\end{array}$} & \multirow{2}{*}{$\begin{array}{c}\text { Absolute growth } \\
\text { rate } \\
\text { (g plant/day/1) } \\
\text { 30-60 DAS }\end{array}$} & \multirow{2}{*}{$\begin{array}{c}\text { Crop growth } \\
\text { rate }\left(\mathbf{g ~ m}^{-2} /\right. \\
\text { day }) \\
\text { 30-60 DAS }\end{array}$} & \multirow[t]{2}{*}{$\begin{array}{c}\text { No. of } \\
\text { cobs/plant }\end{array}$} & \multirow{2}{*}{$\begin{array}{c}\text { Length } \\
\text { of cobs } \\
(\mathrm{cm})\end{array}$} & \multirow{2}{*}{$\begin{array}{c}\text { Girth } \\
\text { of cob } \\
(\mathrm{cm})\end{array}$} \\
\hline & $\begin{array}{l}\text { At } 30 \\
\text { DAS }\end{array}$ & At harvest & $\begin{array}{l}\text { At } 30 \\
\text { DAS }\end{array}$ & $\begin{array}{l}\text { At } 60 \\
\text { DAS }\end{array}$ & & & & & \\
\hline \multicolumn{10}{|c|}{ Organic manure (M) } \\
\hline $\mathbf{M}_{1}$ & 1209.7 & 2304.0 & 1.01 & 1.92 & 1.85 & 15.43 & 1.37 & 13.10 & 11.76 \\
\hline $\mathbf{M}_{2}$ & 1913.4 & 3739.6 & 1.59 & 3.12 & 2.19 & 18.21 & 1.47 & 16.68 & 14.47 \\
\hline $\mathbf{M}_{3}$ & 1560.1 & 3017.4 & 1.30 & 2.51 & 2.08 & 17.30 & 1.46 & 15.55 & 13.62 \\
\hline $\mathbf{M}_{4}$ & 2000.7 & 3963.3 & 1.67 & 3.30 & 2.18 & 18.12 & 1.47 & 16.42 & 14.19 \\
\hline S.Em. \pm & 43.3 & 78.2 & 0.04 & 0.07 & 0.04 & 0.35 & 0.03 & 0.28 & 0.19 \\
\hline C. D. at $5 \%$ & 121.5 & 219.6 & 0.10 & 0.18 & 0.12 & 0.98 & $\mathrm{NS}$ & 0.79 & 0.52 \\
\hline \multicolumn{10}{|c|}{ Inorganic fertilizer $(F)$} \\
\hline $\mathbf{F}_{1}$ & 1537.4 & 3008.8 & 1.28 & 2.51 & 2.03 & 16.88 & 1.41 & 14.99 & 13.21 \\
\hline $\mathbf{F}_{2}$ & 1804.5 & 3503.3 & 1.50 & 2.92 & 2.12 & 17.65 & 1.47 & 15.89 & 13.81 \\
\hline S.Em. \pm & 30.6 & 55.3 & 0.03 & 0.05 & 0.03 & 0.25 & 0.02 & 0.20 & 0.13 \\
\hline C. D. at $5 \%$ & 85.9 & 155.3 & 0.07 & 0.13 & 0.08 & 0.69 & NS & 0.56 & 0.37 \\
\hline \multicolumn{10}{|l|}{ Sulphur (S) } \\
\hline $\mathbf{S}_{1}$ & 1637.2 & 3181.3 & 1.36 & 2.65 & 2.04 & 17.03 & 1.41 & 15.24 & 13.42 \\
\hline $\mathbf{S}_{2}$ & 1704.7 & 3330.8 & 1.42 & 2.78 & 2.10 & 17.50 & 1.47 & 15.63 & 13.60 \\
\hline S.Em. \pm & 30.6 & 55.3 & 0.03 & 0.05 & 0.03 & 0.25 & 0.02 & 0.20 & 0.13 \\
\hline C. D. at $5 \%$ & NS & NS & NS & NS & NS & NS & NS & NS & NS \\
\hline Interaction & - & - & - & - & - & - & - & $\mathrm{MxF}$ & $\mathrm{MxF}$ \\
\hline C. V. \% & 14.65 & 13.58 & 14.65 & 13.58 & 11.40 & 11.40 & 12.09 & 10.34 & 7.78 \\
\hline
\end{tabular}


Table.3 Effect of direct and residual effect of organic and inorganic nutrient sources on maize yield attributes and yield (pooled of Two years)

\begin{tabular}{|c|c|c|c|c|}
\hline Treatment & $\begin{array}{c}\text { Average weight } \\
\text { of cob (g) }\end{array}$ & $\begin{array}{l}\text { Seed index } \\
\text { (g) }\end{array}$ & $\begin{array}{l}\text { Seed yield } \\
\text { (kg/ha) }\end{array}$ & $\begin{array}{c}\text { Straw yield } \\
\text { (kg/ha) }\end{array}$ \\
\hline \multicolumn{5}{|c|}{ Organic manure (M kg/ha) } \\
\hline $\mathbf{M}_{1}$ & 112.2 & 21.2 & 2980 & 4857 \\
\hline $\mathbf{M}_{2}$ & 129.7 & 24.4 & 4249 & 6420 \\
\hline $\mathbf{M}_{3}$ & 118.3 & 23.5 & 4028 & 6136 \\
\hline $\mathbf{M}_{4}$ & 121.4 & 23.9 & 4166 & 6266 \\
\hline S.Em. \pm & 2.53 & 0.47 & 78.88 & 101.08 \\
\hline C. D. at $5 \%$ & 7.11 & 1.31 & 222 & 284 \\
\hline \multicolumn{5}{|c|}{ Inorganic fertilizer (F kg/ha) } \\
\hline $\mathbf{F}_{1}$ & 115.2 & 22.5 & 3679 & 5705 \\
\hline $\mathbf{F}_{2}$ & 125.7 & 24.1 & 4033 & 6134 \\
\hline S.Em. \pm & 1.79 & 0.33 & 55.78 & 71.47 \\
\hline C. D. at $5 \%$ & 5.03 & 0.92 & 157 & 201 \\
\hline \multicolumn{5}{|l|}{ Sulphur (S kg/ha) } \\
\hline $\mathbf{S}_{1}$ & 116.7 & 22.8 & 3739 & 5821 \\
\hline $\mathbf{S}_{2}$ & 124.2 & 23.7 & 3973 & 6018 \\
\hline S.Em. \pm & 1.79 & 0.33 & 55.78 & 71.47 \\
\hline C. D. at $5 \%$ & 5.03 & NS & 157 & NS \\
\hline Interaction & $\mathrm{MxF}$ & - & $\mathrm{MxF}$ & $\mathrm{MxF}$ \\
\hline C. V. \% & 11.89 & 11.32 & 11.57 & 9.66 \\
\hline
\end{tabular}

Table.4 Interaction effects organic manure and inorganic fertilizer on Plant height at 60 DAS, length of cob, girth of cob, average weight of cob, seed and straw yield

\begin{tabular}{|c|c|c|c|c|c|c|c|c|c|c|c|c|}
\hline \multirow{3}{*}{$\begin{array}{c}\text { Organic } \\
\text { manure (M) }\end{array}$} & \multicolumn{12}{|c|}{ Inorganic fertilizer $(\mathbf{F})$} \\
\hline & \multicolumn{2}{|c|}{ Plant height at 60 DAS $(\mathrm{cm})$} & \multicolumn{2}{|c|}{ Length of $\mathrm{cob}(\mathrm{cm})$} & \multicolumn{2}{|c|}{ Girth of $\operatorname{cob}(\mathrm{cm})$} & \multicolumn{2}{|c|}{ Average weight of cob $(\mathrm{g})$} & \multicolumn{2}{|c|}{ Seed yield (kg/ha) } & \multicolumn{2}{|c|}{ Straw yield (kg/ha) } \\
\hline & $\mathrm{F}_{1}$ & $\mathrm{~F}_{2}$ & $\mathrm{~F}_{1}$ & $\mathrm{~F}_{2}$ & $\mathrm{~F}_{1}$ & $\mathrm{~F}_{2}$ & $\mathrm{~F}_{1}$ & $\mathrm{~F}_{2}$ & $\mathrm{~F}_{1}$ & $\mathrm{~F}_{2}$ & $\mathrm{~F}_{1}$ & $\mathbf{F}_{2}$ \\
\hline $\mathbf{M}_{1}$ & 136.0 & 135.2 & 12.40 & 13.79 & 11.79 & 11.73 & 112.93 & 111.55 & 2870 & 3091 & 4592 & 5122 \\
\hline $\mathbf{M}_{2}$ & 144.3 & 162.6 & 15.54 & 17.82 & 14.08 & 14.86 & 118.30 & 131.00 & 3952 & 4547 & 6492 & 6564 \\
\hline $\mathbf{M}_{3}$ & 143.2 & 150.8 & 15.91 & 15.20 & 13.60 & 13.65 & 110.83 & 125.86 & 3668 & 4388 & 5708 & 6348 \\
\hline $\mathbf{M}_{4}$ & 143.5 & 157.5 & 16.10 & 16.74 & 13.37 & 15.01 & 118.66 & 124.22 & 4107 & 4225 & 6029 & 6504 \\
\hline S.Em. + & \multicolumn{2}{|c|}{3.05} & \multicolumn{2}{|c|}{0.40} & \multicolumn{2}{|c|}{0.26} & \multicolumn{2}{|c|}{3.58} & \multicolumn{2}{|c|}{111.5} & \multicolumn{2}{|c|}{143} \\
\hline C. D. at $5 \%$ & \multicolumn{2}{|c|}{8.6} & \multicolumn{2}{|c|}{1.12} & \multicolumn{2}{|c|}{0.74} & \multicolumn{2}{|c|}{10.06} & \multicolumn{2}{|c|}{313} & \multicolumn{2}{|c|}{401} \\
\hline
\end{tabular}


The higher growth, yield attributes and yield under treatment combination $\mathrm{M}_{2} \mathrm{~F}_{2}$ might be due to the nutrients from fertilizers were available to the crop at the early stages and through organic manures at later stages of the crop growth. Organic manure also supply essential nutrient to the soil and increase the availability of nutrient for longer period due to slow release and application of inorganic fertilizer consequently supply of photosynthates for the formation of yield components.

The girth of cob $(15.01 \mathrm{~cm})$ was significantly higher under treatment combination of $\mathrm{M}_{4} \mathrm{~F}_{2}$. Girth of cob was increased by application of organic manure and inorganic fertilizers might be due to stimulating effect on the progressive development of roots due to increase in nutrient availability especially nitrogen and phosphorus in soil which favourably improved growth

The overall results inferred that kharif maize crop fertilized with recommended dose of inorganic fertilizer 120-60-00 kg NPK/ha and $20 \mathrm{~kg}$ sulphur/ha alongwith FYM @ 10 t/ha gave maximum growth and yields of maize.

\section{Acknowledgement}

Authors are very much thankful to the Director of Research and Dean P.G. Studies, AAU, Anand; Principal and Dean, B.A.College of Agriculture and Professor and Head, Department of Agronomy and my guide for valuable guidance and support during research program and to obtain its significant findings.

\section{References}

Ashoka, P., Khot, B. A. and Neelkanth, J. K. (2013). Integrated nutrient management in maize- bengal gram cropping system in vertisols. Environment \& Ecology.,
31 (3): 1337-1340.

Chandrashekar C. P. (2013). Performance of maize hybrid as influenced by different levels of nitrogen, phosphorus, potassium and sulphur aaplication. Karnataka J. Agric. Sci., 26 (2): 194199.

Cochran, W. G. and Cox, G. M. (1957). Experimental designs, John Willey and Sons. Inc., NewYork, 546-568.

De, Gopal Chandra (1990). Fundamentals of Agronomy, Oxford and IBH publishing Co. Pvt. Ltd., New Delhi.

Dechassa H. C. S., Hiremath S. M., Awaknavar J. S., Wali M. C., Nadagouda

Kothari, S.K. and Saraf, C.S. (1988). Studies on phosphorus utilization as influenced by bacterial seed inoculation and phosphorus fertilization in summer mung [Vignaradiata(L.)Wilczek]. $J$. Agric. Biol. 17: 34-38.

Kumar, M.; Singh, M. and Ahmed, P. (2002). Effect of different levels of nitrogen and phosphorus on growth and yield of maize in Nagaland. Extended summaries, Vol. 1: $2^{\text {nd }}$ Int. Agron. Cong. held at New Delhi during 26-30 Nov., 2002, pp. 202-203.

Kumar, S. N. and Singh, C. P. (2001). Growth analysis of maize during long and short duration crop seasons: influence of nitrogen source and dose. Indian $J$. Agric. Res., 35(1) : 13-18.

Kundu, S. and Prasad, J. V. N. S. (2010). Direct and residual effect of integrated sulphur fertilization in maize- chickpea cropping system on Typicustochrept. Indian J. Agron., 55 (4): 259-263.

Manjhi R. P., Mahapatra P., Shabnam S., Yadava M. S. (2016). Long term effect of nutrient management practices on performance of quality protein maize under maize- wheat cropping sequence. Indian J. Agron., 61 (4): 436-442.

Meena K. N., Kumar A., Rana D. S and 
Meena M. C. (2011). Productivity and nutrient uptake of maize- wheat cropping system under different biosources and nitrogen levels. Indian $J$. Agron., 56 (3): 182-188.

Mukherjee D. (2014). Influence of integrated nutrient management on productivity, nutrient uptake and economics of maize- yellow sarson cropping system under rainfed mid hill condition. Indian J. Agron., 59 (2): 221-228.

Munda, G. C., Islam, M. and Nath, L. K. (2011). Integrated nutrient management approach for enhancing productivity and economics of maize- toria cropping system. Agric. Sci. Digest., 31 (3): 188192.

Rajkumara S., Aladakatti Y. R., Patil P. L. and Khot A. B. (2009). Nitrogen and phosphorus substitution through organics in maize- chickpea sequence under irrigated conditions. Karnataka J. Agric. Sci., 22 (1):15-17.

Rajkumara, S., Gundlur, S. S. and Khot, A. B. (2012). Effect of continuous application of organics to supply nitrogen and phosphorus on maize and chickpea under irrigated condition. Indian J. agril. Sci.., 82 (10): 892-895.

Srinivasanarao.,Massod, Ali., Venkateswarlu, S., Rupa, T. R., Singh, K. K.,

Tetarwal, J. P., Baldev, R. and Meena, D. S. (2011). Effect of integrated nutrient management on productivity, profitability, nutrient uptake and soil fertility in rainfed maize (Zea mays L.). Indian J. Agron., 56 (4): 373-376.

Watson, D. J. (1952). The Physiological basis of variation in yield. Adv. Agron., 4, 101-145.

\section{How to cite this article:}

Lakum. Y. C., H. K. Patel, G. G. Patel, C. F. Makwana and Patel. P. D. 2020. Yield and Yield Attributes of Maize as Influenced by Organic Manures and Inorganic Fertilizers under Maize Chickpea Cropping Sequence. Int.J.Curr.Microbiol.App.Sci. 9(07): 994-1003. doi: https://doi.org/10.20546/ijcmas.2020.907.117 